\title{
Study on the Influence of Socialist Core Values on College Students in the New Media
}

\author{
Chenxi Shi \\ Heilongjiang University of Chinese Medicine, Jiamusi, Heilongjiang, 154007
}

Keywords: Socialist Core Values, College Students, New Media

\begin{abstract}
Since the new century, with the Internet, mobile phones as the representative of the rapid development of new media, the way of thinking, lifestyle, learning patterns, interpersonal relationships, values had a tremendous impact. On the whole, the mainstream of college students' values is positive and healthy, but there are many problems that can not be ignored and solved urgently. Therefore, it is necessary to strengthen the research on the socialist core values of college students in the view of new media, to enhance the attractiveness and cohesion of socialist ideology, to improve the effectiveness of ideological and political education of college students, to promote the healthy growth of college students, to ensure the succession of socialism with Chinese characteristics Some people have significant and far-reaching significance.
\end{abstract}

\section{Introduction}

"Cultivate what people, how to cultivate people" is the fundamental problem of education and eternal theme. The 18th National Congress of the Communist Party of China put forward the idea of "cultivating the moral and spiritual development of moral, intellectual and moral development" as the fundamental task of education, and emphasizing "actively cultivating and practicing the socialist core values, Master the leadership and leadership of ideological work, adhere to the correct orientation, improve the ability to guide and grow the mainstream of public opinion, "which for the university personnel training put forward new requirements, but also pointed out the direction. The Education of College Students 'Socialist Core Values is an Important Content of College Students' Ideological and Political Education. The 21st century is the information age, with the progress of science and technology, the Internet, mobile phones, digital TV as the representative of the new media is profoundly changing people's daily life, way of thinking and values, especially in contemporary college students have a wide range of impact, So that college students ideological and political education is facing many new situations and new problems and new tasks. New media is a "double-edged sword", to the ideological and political education of college students to bring new opportunities, but also brought serious challenges. How to make good use of the advantages and disadvantages, make full use of the new media to innovate the ideological and political education of college students, expand the socialist social values of college students a new way to become the current colleges and universities must face and effectively solve the major issues.

\section{The Great Significance of the Education of Socialist Core Values in College Students}

Values, is the people on some kind of people on the value of certain things the basic view, the general concept. The belief that the faith, the ideal, the people choose the value of the kind of things and guide the main behavior of the value of the pursuit of the model. Values are generally divided into two categories: general values and core values. The socialist core values refer to the values that dominate the socialist value system and play a decisive role in guiding the values that reflect the basic and stable social relations and values of socialism. It is the most value in the socialist value system. The core part of the foundation and the core part is the crystallization of the fundamental principles and values of our nation's long-term adhering to the essence of socialism and the law of construction. It is the gradual formation of the Chinese Communists and all the Chinese people in 
the process of socialist revolution, construction and reform. The socialist core values and the socialist core value system are two existing and different concepts. "The socialist core values are the core of the socialist core value system, which embodies the fundamental nature and basic characteristics of the socialist core value system, and reflects the fact that the socialist core values are the core of the socialist core value system, The rich connotation and practical requirements of the socialist core value system are the highly concise and concentrated expression of the socialist core value system. This is the core values and core values of the relationship between the two basic positioning.

\section{The Influence of New Media on the Education of College Students' Socialist Core Values}

The traditional college students ideological and political education is the teacher said, students listen, the teacher asked, the students answer, teachers and students can only interact in a limited time interaction between teachers and students is difficult to open the interaction between the heart of the exchange. The new media has the characteristics of equal interaction, open sharing and so on. It enhances the interaction between educators, college students and society, and creates a more relaxed, more free and pleasant learning and communication environment for college students to accept the socialist core values. Timely and easy is to participate in the feedback of information, through the forum exchange, debate and other ways to start a proactive thinking exchange. According to the author's survey, asked, "Do you often participate in network public opinion activities, such as: forum post, blog message, QQ space to talk about" problem, $85 \%$ of students choose "regular", 13\% of students choose "occasionally".

The traditional ideological and political education of college students, more lectures, discussions, meetings, individual talks and other forms, to take the facts, reasoning education methods, it is difficult to take into account the ideological basis of education, acceptance and personality characteristics of differences, easy There is a "one size fits all", "one speech", "full house irrigation" phenomenon, affecting the enthusiasm of the object of education and initiative. The emergence of new media breakthrough time and space constraints, students can through the Internet, mobile phones, Internet TV and other media is very convenient access to learning materials; colleges and universities can also actively use the new media "by boat", through micro-blogging, blog, QQ space, network forum and other college students happy to see the way to carry out the socialist core values education, to attract students' attention and recognition, enrich the socialist core values of college students education methods and ways to achieve the use of new media and college students socialist core values education win effect. According to the author's survey, $80 \%$ of the students chose "QQ, e-mail, WeChat, microblogging, blog", 51\% of the students who asked "when you were dealing with people around you," Students choose "interviews, meetings, lectures and other forms", 19\% of students choose "BBS forum, all network and other network community."

In the traditional mode of ideological and political education, most of the information from radio, newspapers, television and education, due to their own physical restrictions, it is impossible to achieve full sharing, it is impossible for college students to use anytime, anywhere. The Internet as a large interactive multimedia can effectively focus on the parties to the integration of communication systems, a large capacity, high-speed data transmission system, so that the source of ideological and political education information diversified, more informative content. Such as Sohu, Sina, NetEase and other different sites at any time constantly updated information content, rolling out of the show. Students can not only through the network platform, 3G mobile phones, ipad and other Internet access at any time, but also through mobile microblogging, QQ, Fetion, etc. to achieve anytime, anywhere access to a large number of information resources. The characteristics of this massive information content of new media not only provide a large amount of new educational content and material for college students 'socialist core values education, but also enrich the information resources of college students' socialist core values education. 


\section{The Countermeasures of College Students' Socialist Core Values Education from the Perspective of New Media}

The ideological and political theory course of college is the main channel of ideological and political education of college students, and it is important to cultivate contemporary college students to establish the correct world outlook, outlook on life and values, so that they become the cause of socialism with Chinese characteristics qualified builders and reliable successors important responsibilities. There is no doubt that knowledge transfer and value guidance are the main responsibilities of ideological and political theory course in colleges and universities. Therefore, the ideological and political theory course in colleges and universities has special status and function in cultivating college students' socialist core values.

Colleges and Universities Should Integrate the Education of Socialist Core Values into the Courses of Ideological and Political Theory. In view of the different characteristics of college students' different majors, different grades, different colleges and universities, the core values of different students, the core planning and revision of the ideological and political theory courses in colleges and universities in time to ensure that the socialist core values into the teaching materials , Into the minds of college students. Such as the "basic principles of Marxism" class should focus on strengthening the "freedom, equality, justice, the rule of law," the socialist core values of education, to clarify the party's eighteen from the social level of the eight core values; "Mao Zedong Thought and Chinese characteristics Socialism theoretical system "class should focus on strengthening the" prosperity, democracy, civilization, harmony, "the socialist core values of education, to clarify the party's eighteen from the national level of the eight core values;" Outline of modern history " This paper puts forward the historical inevitability of the socialist core values by the Party Central Committee and the importance of cultivating and practicing the socialist core values of the contemporary college students. The course of "ideological and moral cultivation and legal basis" should focus on strengthening the " Patriotism, dedication, integrity, friendliness, "the socialist core values of education, to clarify the party's eighteen from the individual level of the eight core values.

The fundamental purpose of education is to promote the growth and development of human beings. This determines that colleges and universities must regard the "Lide tree people" as the fundamental task of education and constantly innovate the educational idea, and firmly establish the new subject of student-centered interaction between teachers and students View. The subjective view of this kind of equality and interaction is not a one-sided view of the teacher's subject, nor is it a one-sided view of the student's subjectivity, but a new subject of dialectical unity of the subjectivity of the educator and the subject of the educated person. The interaction, de-centralization and individuality of the new media coincide with the new subjectivity of the equal interaction with the ideological and political education. In the past, the traditional concept of education emphasizes the main role of educators, educators in the absolute authority and the central position, the educated in a subordinate and passive position, which is difficult to stimulate the awareness of the educated and self-awareness of education, nor In line with the "people - oriented" scientific development concept requirements. We say that the value of identity is educated by the educated, sentiment, letter, meaning, line at a higher level and level of coordination. In the education of value recognition, we should not only play the leading role of teachers in the process of education, but also pay attention to the main role of students in self-education, through the students' self-awareness, self-evaluation, self-supervision, self-adjustment, The dominant ideology and its core values, the formation of value recognition. Therefore, under the new media environment, we must firmly establish the new subject view of student-centered and equal interaction between teachers and students, give full play to the leading role of teachers and the active role of college students, and promote the effectiveness of college students' socialist core values education. 


\section{Conclusion}

The education of college students' socialist core values is an important part of ideological and political education in colleges and universities. With the rapid development of new media technologies such as mobile phones, Internet, digital network television and so on, it has provided new opportunities for innovating the core values education of college students, but also makes the core values of college students' education The severe challenge. How to avoid the negative influence of the new media, give full play to the advantages of new media, and actively expand the socialist core values of college students education space and channels, and continuously enhance the attractiveness of college students socialist core values appeal and effectiveness, to address and solve the major issues.

\section{Acknowledgements}

Research on the socialist core values from the perspective of new media; Xi Jinping Youth ideological and political education research.

\section{References}

[1] Liu Shulin. Cultivation of socialist core values of the basic principles [J]. Ideological and theoretical education, 2013 (03)

[2] Ji Zhe, Xie Chunhu, Zhong Jingfeng. Contemporary college students' core values [J]. Journal of Ideological Education, 2012 (07)

[3] Feng Gang. Reflections on the cultivation of college students' core values [J]. School Party Building and Ideological Education, 2012 (13)

[4] Kan Heqing. Effective path of college students' socialist core values education [J] .Journal of Ideological and Political Work, 2011 (03)

[5] Li Heliang, Liu Yan. Contemporary college students to cultivate the core values [J]. School Party building and ideological education, 2011 (05)

[6] Gong Bin. On the concept of socialist values of several points [J]. Ideological and political work, $2011(02)$ 